\title{
Patch clamp analysis of excitatory synapses in mammalian spinal cord slices
}

\author{
A. Konnerth" ${ }^{1}$ B. U. Keller' ${ }^{1}$, and A. Lev-Tov² \\ 1 Max-Planck-Institut für biophysikalische Chemie, Am Fassberg, W-3400 Göttingen, Federal Republic of Germany \\ 2 Department of Anatomy, The Hebrew University Medical School, Jerusalem 91010, Israel
}

Received March 13, 1990/Received after revision July 23, 1990/Accepted July 31, 1990

\begin{abstract}
Excitatory synaptic transmission to visually identified $\alpha$-moto neurones was studied in thin slice preparations of the neonatal rat spinal cord. Excitatory postsynaptic currents (EPSCs) elicited by stimulation of intraspinal presynaptic fibres were recorded using the whole-cell patch clamp technique, following blockade of inhibitory transmission by bath application of strychnine and bicuculline. The EPSCs could be separated pharmacologically into $N$-methyl-D-aspartate- (NMDA) and non-NMDA-receptor-mediated components, where the contribution of the NMDA-mediated component was significant only at holding potentials more positive than $-50 \mathrm{mV}$. Graded stimulation of intraspinal fibres showed that the NMDA- and the non-NMDA-mediated EPSCs were evoked by activation of presynaptic fibres with similar sensitivities to the stimulation intensity, suggesting that the same presynaptic fibres released the excitatory amino-acid (EAA) activating the two sub-sets of receptors. Studies of the amplitude fluctuations of EPSCs elicited by stimulation of a presumed single fibre revealed similar proportions of transmission failures and similar distributions of both the NMDA- and the nonNMDA-mediated components. These similarities suggest that the EAA transmitter activating the two sub-types of receptors is released from the same set of synaptic boutons and that the receptors are therefore postsynaptically co-localized. In addition the gamma aminobutyric acid $_{B}\left(G_{A B A}\right)$ receptor agonist $\mathrm{L}$-baclofen, which is known to decrease transmitter release, changed the amplitude distributions of non-NMDA- and NMDAreceptor-mediated EPSCs into unimodal distributions without affecting the amplitude of the presumed unitary event. The similarity between the transmitter release profiles of the two EAA components further supports the notion of postsynaptic receptor co-localization.
\end{abstract}

Key words: Spinal moto neurones - Excitatory synaptic transmission - NMDA and non-NMDA receptors Patch clamp - Thin slice

Offprint requests to: A. Konnerth

\section{Introduction}

The excitatory synaptic drive of central nervous system (CNS) neurones is one of the key factors determining information transfer between elements of the neuronal network. Studies of excitatory transmission in the CNS are complicated by the inability to control the ionic environment of the neurones in vivo, and by the difficulties in obtaining high-resolution recordings of synaptic membrane currents from neurones in CNS preparations with well preserved synaptic organization. However, the recent application of the patch clamp technique (Hamill et al. 1981) to slice preparations of the CNS (Edwards FA et al. 1989) has overcome these difficulties: functional synaptic inputs to visually identified neurones can be easily activated, the central neurone can be voltage clamped over a wide range of membrane potentials and the composition of the external and internal environments of the neurones can be controlled.

In this study, we used whole-cell patch clamp recordings from visually identified moto neurones in thin spinal cord slices from neonatal rats, and stimulation of intraspinal excitatory fibres to characterize central excitatory synaptic transmission. The results provide evidence that:

1. Excitatory spynaptic input to moto neurones in the neonatal rat spinal cord is mediated by simultaneous activation of $N$-methyl-D-aspartate (NMDA) and nonNMDA subtypes of excitatory amino-acid (EAA) receptors.

2. The excitatory transmitter activating these receptor sub-types is released from the same set of presynaptic fibres.

3. The NMDA- and non-NMDA-receptor-mediated single fibre excitatory postsynaptic currents (EPSCs) are generated by release of EAA from the same set of presynaptic boutons, suggesting postsynaptic co-localization of these receptors.

4. The release of EAA from the excitatory synapses in the neonatal rat spinal cord can be modulated effec- 
tively by activation of presynaptic gamma aminobutyric $\operatorname{acid}_{B}\left(\mathrm{GABA}_{\mathrm{B}}\right)$ receptors.

\section{Materials and methods}

Thin transverse slices $(120-140 \mu \mathrm{m}$, see Takahashi 1978) were cut from the lumbar region of the spinal cord of neonatal rats (age 59 days postnatal) in ice-cold modified Krebs solution (composition in $\mathrm{mM}: \mathrm{NaCl} 125 ; \mathrm{KCl} 2.5 ; \mathrm{CaCl}_{2} 2 ; \mathrm{MgCl}_{2} 1 ; \mathrm{NaH}_{2} \mathrm{PO}_{4} 1$; $\mathrm{NaHCO}_{3} 26$; glucose $25 ; \mathrm{pH} 7.3$ ), and then incubated at $37^{\circ} \mathrm{C}$ for at least $45 \mathrm{~min}$. Before recording, the slices were transferred to an experimental chamber which was continuously superfused with oxygenated $\left(95 \% \mathrm{O}_{2}, 5 \% \mathrm{CO}_{2}\right)$ Krebs solution at room temperature $\left(22-24^{\circ} \mathrm{C}\right)$. Spinal moto neurones, identified as the largest visible (Nomarski optics, $\times 40$ water immersion lens) cells in the region of Rexed's lamina IX (see Fig. 1A), were selected and prepared for recordings by cleaning with a stream of the bathing solution applied from a broken micropipette (diameter $5-10 \mu \mathrm{m}$; see Edwards et al. 1989). Electrophysiological recordings were performed using the whole-cell configuration of the patch clamp technique (Hamill et al. 1981), which enables long term ( $40 \mathrm{~min}$ to $3 \mathrm{~h}$ ), stable recordings from each moto neurone. Visually identified moto neurones could be characterized by brief action potentials accompanied by prolonged after-hyperpolarizations using current-clamp recordings (see Takahashi 1990). The solution in the patch pipette for these current clamp recordings consisted of (in $\mathrm{mM}$ ): $\mathrm{KCl} 140, \mathrm{MgCl}_{2} 2$, adenosine triphosphate, sodium salt (Na-ATP) 4, ethylenebis(oxonitrilo)tetraacetate (EGTA) 10, 4-(2-hydroxyethyl)-1-piperazineethanesulfonic acid (HEPES) 10, pH 7.3. The intracellular solution used in voltage clamp recordings of excitatory synaptic currents (most of the recordings in the present study), was modified by substitution of $\mathrm{KCl}$ in the patch pipette with $120 \mathrm{mM} \mathrm{CsCl}$, and by addition of $20 \mathrm{mM}$ tetraethylammonium chloride (TEA-C).

Excitatory transmission was studied following blockade of inhibitory glycinergic and $\mathrm{GABA}_{\mathrm{A}}$-ergic transmission by the addition of strychnine $(0.5 \mu \mathrm{M})$ and bicuculline $(10 \mu \mathrm{M})$ to the bathing media. Short latency EPSCs were evoked by extracellular stimulation a 4- $\mu \mathrm{m}$ - to $6-\mu \mathrm{m}$-diameter micropipette filled with the experimental bathing solution (pulse duration $200 \mu \mathrm{s}$, stimulation rate $0.5 \mathrm{~Hz}$ ) of intraspinal fibres in the ventral horn, about $100-200 \mu \mathrm{m}$ away from their presumed termination on the somatodendritic membrane (see Fig. 1 A). The adequacy of the voltage clamp of activated excitatory synapses was ensured by selective activation of presumed somatic synapses. This was achieved by positioning the stimulation electrode in regions from which brief EPSCs with a simple waveform and fast rise times could be evoked. Rise times were measured between $10 \%$ and $90 \%$ of the peak EPSC amplitude. Data were continuously recorded using an EPC-7 patch clamp amplifier (List, Darmstadt, FRG), digitized using an A/D converter (Instrutech, New York, USA) and stored for further analysis using a video cassette recorder.

Prior to analysis, data were low-pass filtered at $3 \mathrm{kHz}$ with an 8-pole Bessel filter (Frequency Devices, Haverhill, Massachusetts, USA) and digitized at 50 and $500 \mu \mathrm{s} /$ address for the fast and the slow EPSC components, respectively. The decay time constants of the EPSCs were calculated by exponential curve fitting using an automatic error-minimization algorithm ("Review", Instrutech).

\section{Results}

Whole-cell patch clamp recordings of EPSCs are shown in Fig. 1 B. The EPSCs produced by constant stimulating pulses to lamina IX fibres exhibited synaptic delays of $2-3 \mathrm{~ms}$. These delays were somewhat shorter than those found after dorsal root stimulation in moto neurones from hemisected spinal cord preparations of neonatal rats of the same age (Fulton and Walton 1986; Lev-Tov,
Pinco, Lavi, unpublished data). The EPSCs also showed substantial amplitude fluctuations, most likely due to quantal variations in transmitter release (Katz 1969; Martin 1977; Korn and Faber 1987). EPSCs recorded at different holding potentials are shown in Fig. 1 C. At the holding potential of $-60 \mathrm{mV}$, the EPSCs had a fast timecourse, characterized by a rise time of $0.7 \pm 0.4 \mathrm{~ms}$ and a monoexponential decay with a time constant of $3.7 \pm 1.4 \mathrm{~ms}(n=7)$. EPSCs reversed close to $0 \mathrm{mV}$ (Fig. 1 C, middle trace) and were dominated by a slow component at positive holding potentials (Fig. 1 C; upper trace).

The different kinetics of the EPSCs at negative and positive holding potentials suggested that they consisted of two distinct components. Therefore, the current traces at each holding potential were measured at their peak (Fig. 1D, filled squares) and also $20 \mathrm{~ms}$ after the stimulus artefact (Fig. 1D, circles) resulting in a linear and an Nshaped current/voltage relation, respectively. Both components reversed at about $0 \mathrm{mV}$.

In order to characterize the postsynaptic receptors mediating these two excitatory components we used specific antagonists. Addition of $5 \mu \mathrm{M}$ 6-cyano-7 nitroquinoxaline-2,3-dione (CNQX), which is known to be a potent blocker of non-NMDA receptors (Honoré et al. 1988; Andreasen et al. 1989; Konnerth et al. 1990a), virtually blocked EPSCs at $-60 \mathrm{mV}$ (Fig. 2B). Changing the holding potential to $+40 \mathrm{mV}$ revealed a persisting slow outward component (Fig. 2C). These slow outward currents were characterized by a slow rise time $(5.4 \pm 1.9$ $\mathrm{ms}, n=4)$ and a complex decay lasting several hundreds of milliseconds, similar to those observed under identical conditions in hippocampal granule cells (Konnerth et al. 1990 b). The slow outward EPSC components were completely abolished by $10 \mu \mathrm{M}$ of the specific NMDAreceptor antagonist 3-3(2-carboxypiperazine-4-yl)propyl-1-phosphonate (CPP, Fig. 2D). The effects of CNQX and CPP were reversible after about $10 \mathrm{~min}$ of superfusion with the control solutions.

These data clearly show that excitatory transmission in neonatal $\alpha$-moto neurones is mediated by activation of both NMDA and non-NMDA subtypes of EAA receptors (see McDermott and Dale 1987; Ascher and Nowak 1987 for reviews of EAA receptors). These EPSC components were observed in all moto neurones tested so far $(n=16)$. It should be noted, however, that near the resting potential $(-60$ to $-80 \mathrm{mV})$, the contribution of NMDA-receptor-mediated components to the EPSCs appeared to be negligible (for example see Figs.1D, 2B).

The amplitude of the non-NMDA- and NMDA-receptor-mediated components exhibited similar sensitivity to the intensity of stimulation of the presynaptic elements. The mean amplitudes of the NMDA- and non-NMDAmediated synaptic currents, recorded from the same moto neurone, remained at similar levels over a relatively wide range of stimulus intensities as shown in Fig. 3. However, as the stimulation intensity exceeded a critical value, there was a step-wise increase in both the NMDA- and the non-NMDA-mediated EPSCs to a new level. Additional increases in the stimulus intensity did not augment the EPSCs any further. We infer that the plateaus of EPSCs 

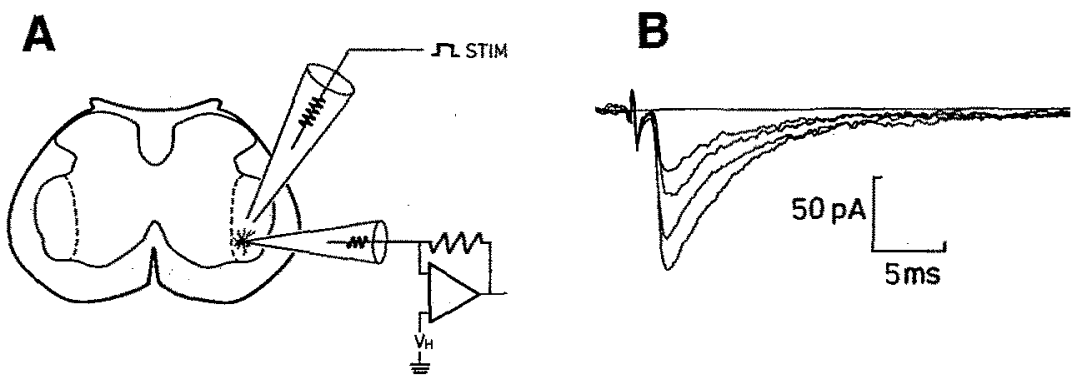

C
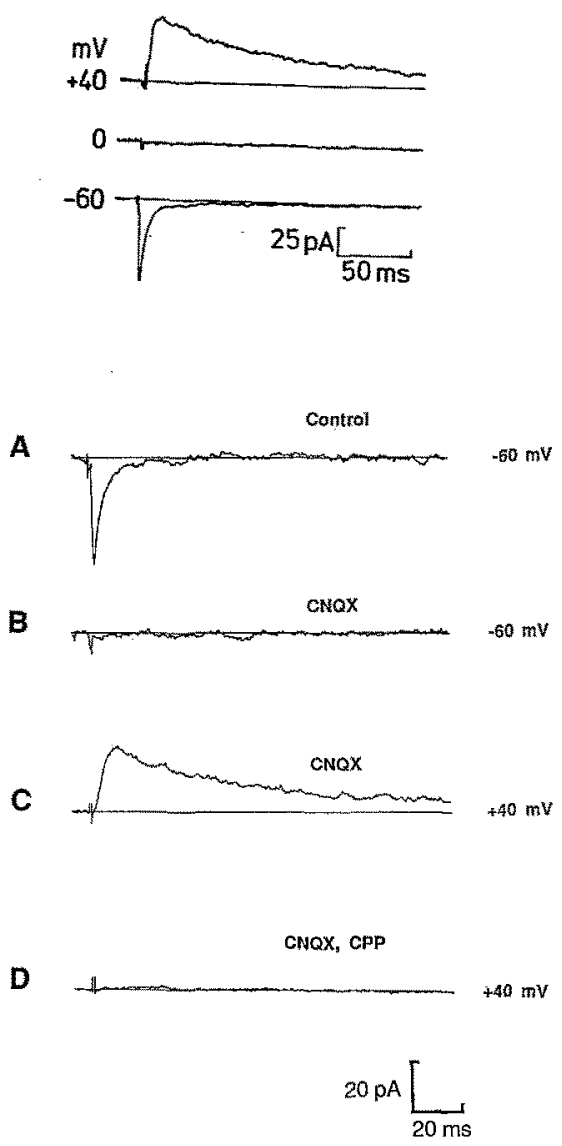

Fig. 2A-D. Pharmacological separation of EPSC components in spinal moto neurones. Computer averaged ( 11 sweeps each) records of EPSCs generated by constant-voltage stimulation of intraspinal presynaptic fibres. A Control EPSC at a holding potential of $60 \mathrm{mV}$. B Abolition of the EPSC at $-60 \mathrm{mV}$ after bath application of $5 \mu \mathrm{M}$ CNQX (6-cyano-7 nitroquinoxaline-2,3-dione). C Slow EPSC recorded from the same cell in the presence of CNQX, after changing the holding potential to $+40 \mathrm{mV}$. D The slow EPSCs recorded at $+40 \mathrm{mV}$ in the presence of ENQX are blocked by addition of $10 \mu \mathrm{M}$ CPP [3-3-(2-carboxypiperazine-4-yl)propyl-1phosphonate]

amplitude resulted from activation of first one, and then two presynaptic afferents. The similar ratio of the nonNMDA- and the NMDA-mediated EPSCs at any stimulation intensity suggests that both components were evoked by activation of the same presynaptic fibres.
Fig. $1 \mathrm{~A}-\mathbf{D}$. Whole-cell patch clamp recordings from a thin spinal cord slice preparation. A Schematic representation of voltage clamp recordings of synaptic currents from visually identified neurones in Rexed's lamina IX (delineated with the dashed lines) generated by extracellular stimulation (STIM) of nearby intraspinal fibres. B Excitatory synaptic currents, evoked by stimulation of intraspinal afferents in an $\alpha$-moto neurone following pharmacological blockade of inhibitory currents. Note the amplitude fluctuations of the individual current traces, despite constant stimulation intensity (see Methods). C Computer averaged records (10 sweeps each) of excitatory postsynaptic currents (EPSCs) recorded at holding potentials of $-60 \mathrm{mV}$ (lower trace), $0 \mathrm{mV}$ (middle trace) and $+40 \mathrm{mV}$ (upper trace). D Current/voltage relations of the fast and the slow components of the EPSCs. The peak amplitudes of averaged EPSCs (10 sweeps each; filled squares) and the amplitudes measured at $20 \mathrm{~ms}$ after the stimulus artefact (circles) are shown as a function of the holding potential. Note the difference in voltage dependence, but the similarity in reversal potential for the fast and the slow components, respectively

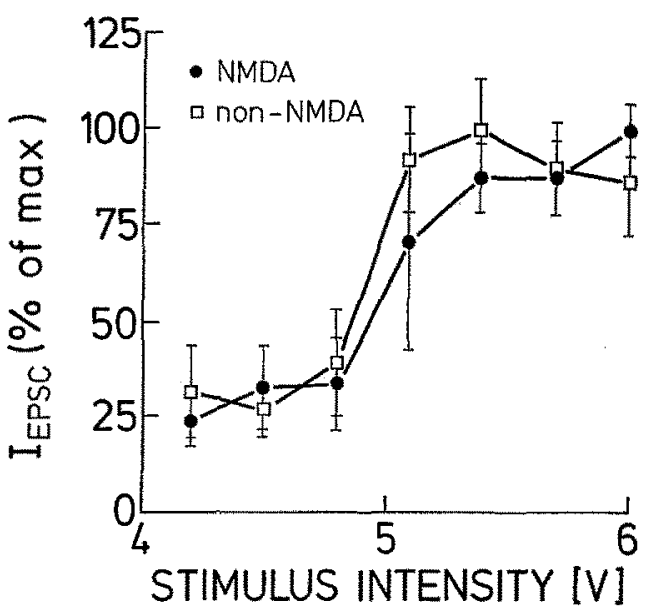

Fig. 3. Sensitivity of the dnal EPSCs to the stimulation intensities. The mean amplitudes of the $N$-methyl-D-aspartate (NMDA), filled circles) and non-NMDA (squares) receptor mediated EPSCs, separated pharmacologically as indicated above, were measured from responses sampled from the same moto neurone at seven different stimulation intensities. The amplitudes of the EPSCs are expressed as percentage of the mean maximal non-NMDA- and NMDAmediated responses, and displayed as a function of the stimulation intensity. The two plateaus, corresponding to the first three and the following four stimulation intensities, respectively, suggest that two presynaptic fibres were activated in this experiment

Using these findings, we adjusted the stimulation intensity to produce EPSCs that fall within the range of the first plateau and, therefore, are presumably generated by activation of a single presynaptic fibre. The analysis of these single fibre EPSCs showed that the patterns of amplitude fluctuations of the NMDA- and non-NMDAreceptor-mediated components were closely similar. The proportions of transmission failures of the non-NMDA 


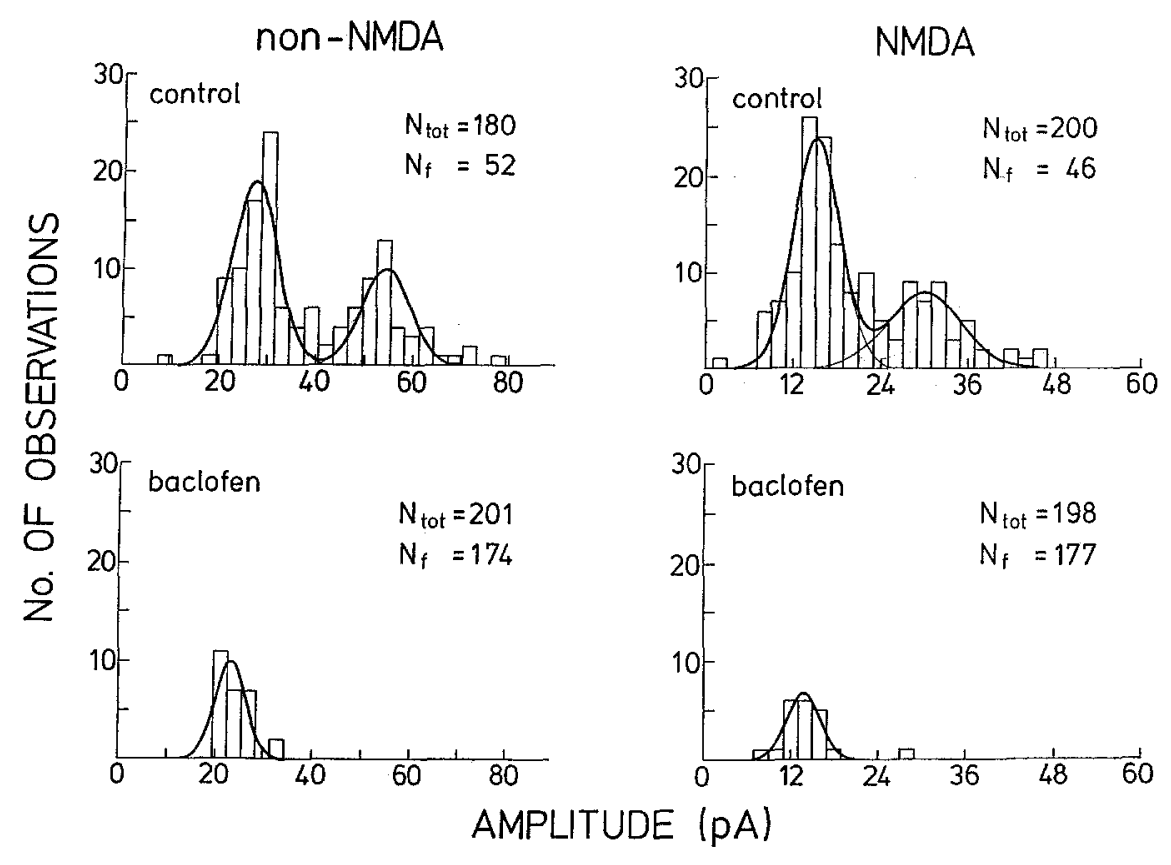

Fig. 4. Amplitude distributions of nonNMDA and NMDA-receptor-mediated components in the same moto neurone upon activation of the same synaptic input. Amplitude histograms of non-NMDA(recorded at holding potential of $-60 \mathrm{mV}$ ), left panel and NMDA- (recorded at $+40 \mathrm{mV}$ in the presence of $5 \mu \mathrm{M} \mathrm{CNQX}$, right panel) mediated EPSCs, generated by activation of a presumed single fibre and sampled from the same cell, before (control) and after

(baclofen) addition of $5 \mu \mathrm{M}$ baclofen to the bathing medium. The histograms were fitted with a summated Gaussian function (solid lines), showing bimodal (control) and then unimodal (baclofen) distributions. The means of the distribution peaks of the non-NMDAreceptormediated component were $27.2 \mathrm{pA}$ and $54.5 \mathrm{pA}$ before, and $23.2 \mathrm{pA}$ after baclofen. The means of the distribution peaks of the NMDA-receptor-mediated component were $15.1 \mathrm{pA}$ and $30 \mathrm{pA}$ before, and $13.8 \mathrm{pA}$ after baclofen. $N_{\text {tot }}=$ Number of trials; $N_{\mathrm{f}}=$ number of transmission failures. Stimulation rate $=0.5 \mathrm{~Hz}$ and NMDA components of the EPSCs were 23\% and $28 \%$, respectively and the amplitude histograms of the non-NMDA- and NMDA-mediated EPSCs (Fig. 4) were both bimodal and well fitted with summated Gaussian functions (Fig. 4, solid lines) with similar proportions of events under each peak. The first peak of the distributions may represent unitary events generated by the release of single transmitter quanta, while the second one may be accounted for by summation of at least two quanta of neurotransmitter. The lower part of Fig. 4 shows the amplitude histograms of single fibre EPSCs mediated by activation of the NMDA and the non-NMDA subtypes of receptors after addition of the $\mathrm{GABA}_{B}$ receptor agonist L-baclofen, which is known to decrease transmitter release in a number of synapses (Shapovalov and Shiriaev 1982; Lev-Tov et al. 1988; Pun and Westbrook 1983; Peng and Frank 1989; Edwards FR et al. 1989; see Bormann 1987, 1988). L-Baclofen reduced the amplitude of the EPSCs substantially and very rapidly. The proportion of transmission failures increased to $89 \%$ and $86 \%$ for the non-NMDA and the NMDA EPSCs, respectively and the amplitude histograms of the non-NMDA- and the NMDA-mediated responses exhibited very similar unimodal distributions (Fig. 4, baclofen). The mean amplitudes of these persisting unitary EPSCs were similar to the respective amplitudes of the non-NMDA and NMDA components of the unitary EPSCs in control amplitude histograms. Thus, L-baclofen apparently reduces the release of EAA, without affecting the mean amplitude of the unitary events.

Further support for the presynaptic site of action of baclofen comes from experiments in which glutamate $(50 \mu \mathrm{M})$ was added to the bath before and after application of L-baclofen, in the presence of the sodium channel blocker tetrodotoxin. The glutamate-induced currents recorded after addition of baclofen $(92.3 \pm 6.9 \mathrm{pA}, n=$
5) were virtually the same as those recorded without baclofen $(90.7 \pm 7.0 \mathrm{pA}, n=5)$.

\section{Discussion}

This study characterises some basic features of excitatory synaptic transmission in visually identified $\alpha$-moto neurones in neonatal mammalian spinal cord slices. The high resolution of the whole-cell patch clamp technique enabled the analysis of low-amplitde synaptic currents, generated by activation of few excitatory synaptic contacts distributed over the moto neurones somata. The selection criteria of somatic EPSCs used in this study appeared to be rather satisfactory. The rise time of the non-NMDA EPSCs at $-60 \mathrm{mV}$ was fairly fast (around $0.7 \mathrm{~ms}$ ), comparable to the rise times observed for somatic inhibitory synapses in hippocampal neurones (Edwards et al. 1990). Both the NMDA and non-NMDA components of the EPSCs exhibited sensitivity to the applied voltage and reversed without displaying biphasic deflections, as reported for the somatodendritic excitatory postsynaptic potentials (EPSCs) recorded in moto neurones from the hemisected spinal cord preparation of the neonatal rat (see Fulton and Walton 1986).

The monoxynaptic EPSCs (see results) recorded in our study could arise from several sources. These include synaptic contacts formed by group Ia stretch receptor afferents (see Burke and Rudomin 1977), as well as other excitatory inputs from monosynaptic pathways (stretch receptor group II afferents and reticulospinal terminations, Baldissera et al. 1981), or synaptic inputs formed by last order neurones of excitatory polysynaptic pathways (descending excitatory pathways and other excitatory interneurones; Burke and Rudomin 1977; Baldissera et at. 1981). We found, however, that regard- 
less of their exact origin, all stimulated presynaptic fibres evoked EPSCs with similar voltage dependence and pharmacological properties. All EPSCs could be distinguished by their differential sensitivity to the specific antagonists of EAA receptors CNQX (Andreasen et a. 1989) and $\mathrm{CPP}$, into non-NMDA- and NMDA-mediated components.

These findings are not unique to the neonatal spinal cord preparation of the rat. Similar components have been described in the embryonic Xenopus spinal cord (Dale and Roberts 1985), as well as in synapses between cultured spinal neurones of the chick (O'Brien and Fischbach 1986), rat (Forsythe and Westbrook 1988), hippocampal cells in culture (Forsythe and Westbrook 1988) and thin slices (Hestrin et al. 1990; Konnerth et al. $1990 \mathrm{~b}$ ). Voltage clamp studies of cat spinal moto neurones, however, did not reveal the slow EPSCs typical to the NMDA-receptor-mediated synaptic currents, at any of the holding potentials (Finkel and Redman 1983). This may be explained by the lower resolution of the single-electrode voltage clamp used in the in situ study, but may also reflect a possible absence, or a significant attenuation, of the NMDA-receptor-mediated component in the EPSCs evoked in mature moto neurones. Additional information regarding this possibility, as well as ideas regarding a possible involvement of NMDAmediated synaptic currents in the plasticity of the developing spinal cord, may be available in the future from whole-cell voltage clamp recordings of synaptic currents from neonatal preparations of different ages.

The number of presynaptic fibres activated in our study as assessed by the graded stimulation experiments, did not exceed two to three in the experiments analysed so far. It is possible, though, that in some cases, two or more fibres with identical thresholds and anatomical locations were activated simultaneously and that the EPSCs were generated by activation of a larger number of fibres. This possibility, however, is rather unlikely since our recordings were obtained by activation of a fairly small population of excitatory contacts to the moto neurone (see Fig. 4). The similar sensitivity of the NMDA and non-NMDA EPSCs elicited in the same cell to a given intensity of stimulation (Fig. 3) suggests that the same presynaptic fibres release the EAA to activate the two receptor sub-types.

Characterization of the release properties of the NMDA and non-NMDA EPSCs, elicited in the same moto neurone by stimulation of a presumed single fibre, was done by a comparative analysis of their amplitude fluctuations. These fluctuations are similar to those described for the endplate potentials in the neuromuscular junction and are thought to reflect the stochastic properties of quantal release of neurotransmitter (Katz 1969; Martin 1977). The high signal-to-noise ratio of the recorded excitatory currents (see Fig.1) permitted a direct analysis of individual EPSCs, without applying the widely used deconvolution technique (Edwards et al. 1976; Wong and Redman 1980; see Korn and Faber 1987) and without imposing statistical models describing the probabilistic nature of quantal release of transmitter (see Korn and Faber 1987; Walmsley et al. 1988).
The notion of postsynaptic co-localization of NMDA and non-NMDA receptors has been implied by a series of binding studies (for review see Cotman et al. 1987) and by a recent patch clamp study on cultured hippocampal neurones (Bekker and Stevens 1989). In our study, this notion is supported by four different lines of evidence: (1) the similarity between the proportion of failures in synaptic transmission of the single fibre NMDA and nonNMDA EPSCs; (2) the close resemblance between the multimodal distributions of the single fibre NMDA and non-NMDA EPSCs; (3) the identical changes in these distributions as transmitter release was reduced by application of L-baclofen; and (4) the finding of NMDA and non-NMDA components in every cell, regardless of the number of presynaptic fibres activated. Thus, our results strongly indicate that the two sub-types of EAA receptors are postsynaptically co-localized at this in situ spinal cord synapse.

Acknowledgements. We thank R. E. Burke, J. W. Fleshman and M. B. Jackson for their critical review of the manuscript, and F. Friedlein for technical assistance. Supported by the Deutsche Forschungsgemeinschaft (grant SFB 236) and Bundesminister für Forschung und Technologie to A. K.

\section{References}

Andreasen M, Lambert JDC, Jensen MS (1989) Effects of new non$N$-methyl-D-aspartate antagonists on synaptic transmission in the in vitro rat hippocampus. J Physiol (Lond) 414:317-336

Ascher P, Nowak L (1987) Electrophysiological studies on NMDA receptors. Trends Neurosci 10:284-288

Baldissera F, Hultborn H, Illert M (1981) Integration in spinal neuroneal systems. In: Brooks VB (ed) Handbook of physiology, vol II, part 1. American Physiological Society, Bethesda, Md, pp 509-595

Bekkers JM, Stevens CF (1989) NMDA and non-NMDA receptors are co-localized at individual excitatory synapses in cultured rat hippocampus. Nature $341: 230-233$

Bormann $J(1988)$ Electrophysiology of $\mathrm{GABA}_{A}$ and $\mathrm{GABA}_{B}$ receptor subtypes. Trends Neurosci 11:112-116

Burke RE, Rudomin P (1977) Spinal neurones and synapses. In: Kandel ER (ed) Handbook of physiology, vol 1, part 2. American Physiological Society, Bethesda, Md, pp 877-944

Cotman CW, Monaghan DT, Ottersen OP, Storm-Mathiesen J (1987) Anatomical organization of excitatory amino acid receptors and their pathways. Trends Neurosci $7: 273-279$

Dale N, Roberts AJ (1985) Dual-component amino-acid mediated synaptic potentials: excitatory drive for swimming in Xenopus embryos. J Physiol 363:35-59

Edwards FA, Konnerth A, Sakmann B, Takahashi T (1989) A thin slice preparation for patch clamp recordings from neurones of the mammalian central nervous system. Pflügers Arch 414:600-612

Edwards FA, Konnerth A, Sakmann B (1990) Quantal synaptic transmission in the central nervous system. A patch clamp study of IPSCs in rat hippocampal slices. J Physiol (Lond) (in press)

Edwards FR, Redman SJ, Walmsley B (1976) Statistical fluctuations in charge transfer at Ia synapses on spinal motoneurones. $J$ Physiol (Lond) 259:665-688

Edwards FR, Harrison PJ, Jack JJB, Kullmann DM (1989) Reduction by baclofen of monosynaptic EPSCs in lumbosacral motoneurones of the anaesthetized cat. J Physiol (Lond) $416: 539-556$

Finkel AS, Redman SJ (1983) The synaptic current evoked in cat spinal motoneurones by impulses in single group $1 \mathrm{a}$ axons. $J$ Physiol (Lond) 342:615-632 
Forsythe ID, Westbrook GL (1988) Slow excitatory postsynaptic curents mediated by $N$-methyl-D-aspartate receptors on cultured mouse central neurones. J Physiol (Lond) 396:515- 533

Fulton BP, Walton K (1986) Electrophysiological properties of neonatal rat motoneurons studied in vitro. J Physiol 370:651-678

Glenn II, Burke RF, Fleshman JW, Lev-Tov A (1983) Estimates of electrotonic distance of group Ia contacts on rat alpha motoneurons. An HRP morphological study. Soc Neurosci Abstr 8:995

Hamill OP, Marty A, Neher E, Sakmann B, Sigworth FJ (1981) Improved patch clamp technique for high resolution current recording from cells and cell free patches. Pflügers Arch $391: 85-100$

Hestrin S, Nicoll RA, Perkel DJ, Sah P (1990) Analysis of excitatory synaptic action in pyramidal cells using whole cell recording from rat hippocampal slices. J Physiol (Lond) 422:203-225

Honoré T, Davies SN, Drejer J, Fletcher EJ, Jacobsen P, Lodge D, Nielsen FE (1988) Quinoxalinediones: potent competitive nonNMDA glutamate receptor antagonist. Science 241:701-703

Katz B (1969) The release of neuronal transmitter substances. The Sherrington Lecture no. 10. Liverpool University Press, Liverpool

Konnerth A, Llano I, Armstrong CM (1990a) Synaptic currents in cerebellar Purkinje cells. Proc Natl Acad Sci USA 87:26622665

Konnerth A, Keller BU, Ballani K, Yaari Y (1990b) Voltage sensitivity of NMDA-receptor mediated postsynaptic currents. Exp Brain Res $81: 209-212$

Korn H, Faber DS (1987) Regulation and significance of probabilistic release mechanisms at central synapses. In: Edelman GM, Gall WA, Cowan WM (eds) Synaptic function. Wiley, New York, pp 57-108

Lev-Tov A, Meyers DER, Burke RE (1988) Activation of type B gamma-aminobutyric acid receptors in the intact mammalian spinal cord mimics the effects of reduced presynaptic $\mathrm{Ca}^{++}$ influx. Proc Natl Acad Sci USA 85:5530-5534

Martin AR (1977) Junctional transmission. II. Presynaptic mechanisms. In: Kandel ER (ed) Handbook of physiology, vol I, part 1. American Physiological Society, Bethesda, Md, pp 329-355

McDermott AB, Dale N (1987) Receptors, ion channels and synaptic potentials underlying the integrative actions of excitatory amino acids. Trends Neurosci $10: 280-284$

O'Brien RJ, Fischbach GD (1986) Excitatory synaptic transmission between interneurons and motoneurons in chick spinal cord cell cultures. J Neurosci 6:3284-3289

Peng Y-Y, Frank E (1989) Activation of $\mathrm{GABA}_{\mathrm{B}}$ receptors causes presynaptic inhibition at synapses between muscle spindle afferents and motoneurons in the spinal cord of bullfrogs. J Neurosci 9:1502-1515

Pun RYK, Westbrook GL (1983) Baclofen: Physiological evidence for a presynaptic site of action in spinal cord cultures. Soc Neurosci Abstr 9:1143

Shapovalov AI, Shiriaev BI (1982) Selective modulation of chemical transmission at a dual-action synapse (with special reference to baclofen). Gen Physiol Biophys 1:423-433

Takahashi T (1978) Intracellular recording from visually identified motoneurones in rat spinal cord slices. Proc $\mathrm{R}$ Soc London [Biol] 202:417-421

Takahashi $\mathrm{T}$ (1990) Membrane currents in visually identified motoneurones of neonatal rat spinal cord. J Physiol (Lond) $423: 27-46$

Walmsley B, Edwards FR, Tracey DJ (1988) Nonuniform release probabilities underlie quantal synaptic transmission at a mammalian excitatory central synapse. J Neurophysiol 60:889-908

Wong K, Redman SJ (1980) The recovery of a random variable from a noisy record with application to the study of fluctuations in synaptic potentials. J Neurosci Methods 2:389-409 